\title{
Influence of assemble patterns on bonding strength of glued bamboo
}

\author{
Yu Zheng ${ }^{1 *} \mathbb{C}$, Bao-long Yi ${ }^{2}$, Ya-qi Tong ${ }^{1}$ and Zhen-zhen Peng ${ }^{1}$
}

\begin{abstract}
As a kind of natural composite material, the outer side of bamboo was quite different from its inner side in microscopic structure and mechanical properties. In order to research the effect of these differences on bonding strength of glued bamboo, bamboo strips were bonded by three different forms: outer side to outer side, outer side to inner side and inner side to inner side. Shear strength results indicated that the bamboo sample glued by inner side to inner side has the greatest shear strength value, which is $18.35 \mathrm{MPa}$, and the other two types have similar shear strength values (approximately $14 \mathrm{MPa}$ ). In particular, for the sample glued by outer side to inner side, the broken part is always the outer side. The scanning electron microscope (SEM) images indicated that bamboo fiber cells and parenchyma cells have different failure patterns in compression shear test. For bamboo fiber cells, dominant destruction occurred at the interface between the fibers. And for parenchyma cell, fracture occurred on cell wall and broken the parenchyma cell itself. The interface between bamboo fiber cells was very weak, thus parenchyma cell was the major contributor to shear strength of bamboo. The inner side had higher shear strength because it had higher content of parenchyma cells. The SEM image and shear strength curve also indicated that in the early period of shearing process, the deformed parenchyma cells are in a relax status, and until the later period of shearing process, the parenchyma cells begin to contribute to shear strength.
\end{abstract}

Keywords: Nature composite, Glue bamboo, Bonding strength, Parenchyma cells, Fiber cells

\section{Introduction}

Bamboo is a kind of renewable material, and in recent years, it has attracted increasing attention. Because of its fast-growing speed, high strength and high fracture toughness, bamboo has been expected to be a sustainable alternative for traditional construction materials, such as wood, concrete, steel and timber [1-8].

The bamboo culm is mainly composed of bamboo fiber cells and parenchyma cells [9-14]. Bamboo fiber cell is sclerenchymatous and has excellent mechanical properties [15-17]. The parenchyma cell is hollow and exhibit poor performance on mechanical properties $[4,9,11$, $18,19]$. If we treat bamboo as fiber-reinforced composite material, obviously, bamboo fiber is the reinforcement,

\footnotetext{
*Correspondence: zhengyu1210@126.com

${ }^{1}$ Beijing Research Institute of Synthetic Crystals Co., Ltd, Beijing 10018, China

Full list of author information is available at the end of the article
}

and parenchyma is the matrix. As a kind of biomass materials, bamboo appears uneven on microscopic structure. The content of bamboo fiber decreases from outer side to inner side (along the radius, as shown in Fig. 1). The outer side of bamboo has higher density of bamboo fiber, thus the outer side often has better mechanical performances, like higher tensile strength $[1,4,20]$. Furthermore, this uneven structure caused difference in surface property of outer side and inner side. Comparing with the inner side, the surface of outer side is denser, and harder to be wetted. Surface property has great influence upon bonding performance, thus it is very important to study the effect of different assemble patterns on bonding strength of glue bamboo.

There are some factors that influence the bonding performance, such as wettability [21, 22], contact angle [23] of adhesive and surface roughness [24] of bamboo. In this work, bamboo strips (Phyllostachys edulis, 4 years old) were bonded by three different forms: outer side to outer
Springer Open (c) The Author(s) 2020. This article is licensed under a Creative Commons Attribution 4.0 International License, which permits use, sharing, adaptation, distribution and reproduction in any medium or format, as long as you give appropriate credit to the original author(s) and the source, provide a link to the Creative Commons licence, and indicate if changes were made. The images or other third party material in this article are included in the article's Creative Commons licence, unless indicated otherwise in a credit line to the material. If material is not included in the article's Creative Commons licence and your intended use is not permitted by statutory regulation or exceeds the permitted use, you will need to obtain permission directly from the copyright holder. To view a copy of this licence, visit http://creativecommons.org/licenses/by/4.0/. 


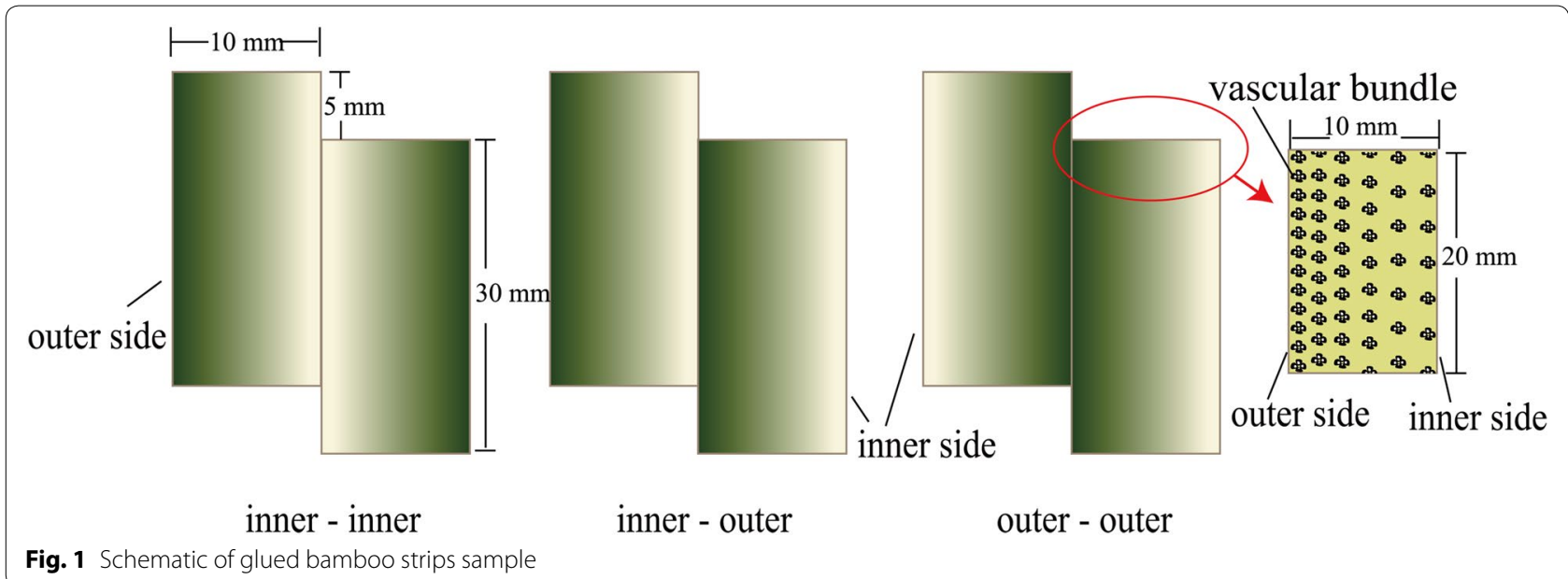

side, outer side to inner side and inner side to inner side. The effect of glued form on bonding strength was also discussed in this research.

\section{Materials and methods}

Bamboo strips (4-year-old Moso bamboo, $20 \mathrm{~mm} \times 30 \mathrm{~mm} \times 10 \mathrm{~mm}$ ), were glued by thermosetting phenolic resin (PF, Taier Chemical Company, Beijing) in this study. The bamboo strips were sanded and were cleaned by ultrasonic to ensure the surface was free from contaminant material. The molecular weight of phenolic resin was about 2000 to 3000 . Bamboo strips were bonded by three different forms: outer side to outer side, outer side to inner side and inner side to inner side, as shown in Fig. 1. Each treatment had 10 repetitive samples. Firstly, bamboo strips were dipped in phenolic resin for $5 \mathrm{~h}$ and then dried in atmosphere for $12 \mathrm{~h}$. Secondly, the bamboo strips which were combined as Fig. 1 were pre-compressed by automatic hot press (3895, CARVER Co., Ltd., USA) at $25 \mathrm{MPa}$ for $10 \mathrm{~min}$. The average glued spread rate is $12.4 \mathrm{wt} \%$, and the bamboo surfaces were fully covered with phenolic resin. Lastly, the pre-compressed bamboo samples were cured by microwave oven at $100{ }^{\circ} \mathrm{C}$ for $15 \mathrm{~min}$. In particular, microwave is a kind of high-frequency electromagnetic wave, whose wavelength is between $1 \mathrm{~mm}$ and $1 \mathrm{~m}$, intermediate between infrared and short-wave radio wavelengths. In recent years, microwave has been considered as an alternative energy source for curing process $[25,26]$. Our previous study had found that microwave could cut the curing time of PF by half and made the glued bamboo sample achieve higher bond strength [27]. Thus microwave was employed as the heating method in this study.

Figure 2 shows the morphology of one side of the glued bamboo strip. The average depth of phenolic resin was $73.8 \mu \mathrm{m}$, which means the permeability of phenolic resin

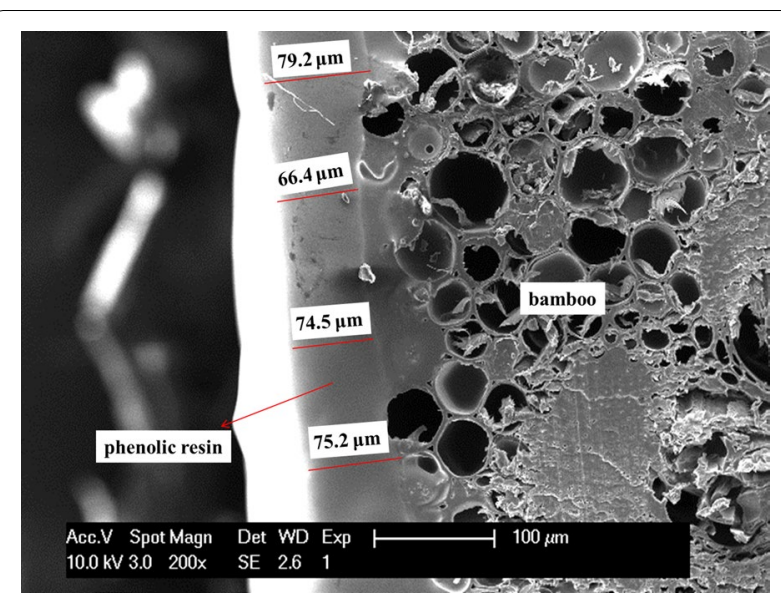

Fig. 2 Morphology of bamboo strips sample with phenolic resin

was good enough to assure samples had strong glue bond strength.

Scanning electron microscope (SEM, FEG-ESEM-L30, FEI, USA) was employed to observe the morphology of cured phenolic resin and glued bamboo.

Bonding strength of bamboo strips was characterized by compression shear test, according to the standard of ISO 6238-2001: adhesives wood-to-wood bonds determination of shear strength by compressive loading. Compression shear strength was tested by Electronic Universal Testing Machine (WDW-E100, Jinan Time Shijin Instrument company, China), and loading speed was $1 \mathrm{~mm} / \mathrm{s}$.

\section{Results and discussion Shear test analysis}

Figure 3 shows the fracture topography of bamboo samples after compression shear test. The three types of glued bamboo are all destroyed at the bamboo region, thus the 


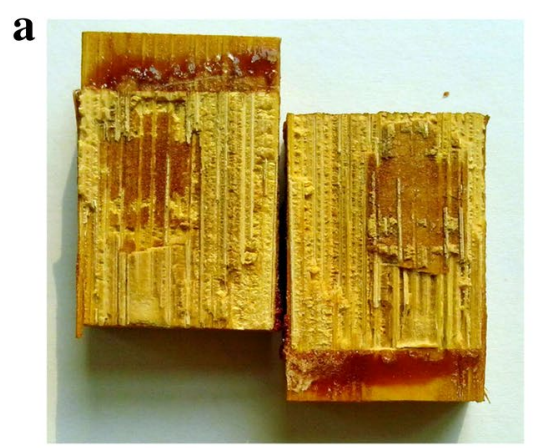

inner-inner b

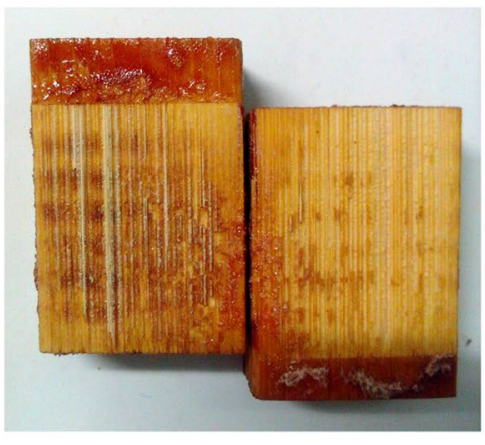

inner-outer c

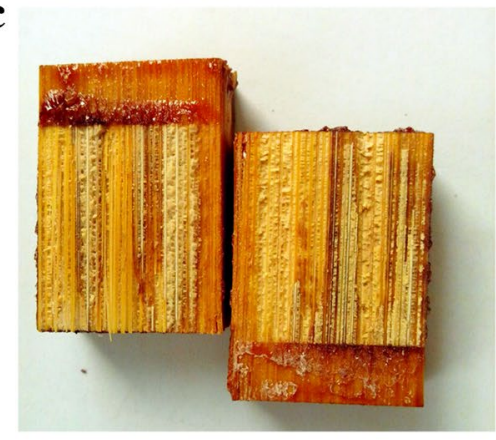

outer-outer

(be broken in the outer side)

Fig. 3 Fracture topography of bamboo samples after compression shear test

bonding strength results of bamboo samples actually reflect the shear strength of bamboo itself. In particular, for the sample glued by outer side to inner side, the broken part is always the outer side. And the fracture topography on inner-outer side is very smooth may cause by lack of glue (just for this sample). In addition, the fracture surface of the inner side is much rougher than the fracture surface of outer side. The failure position and fracture surface topography seem to imply that the inner side is the stronger side under the shear load.

The shear strength results are shown in Fig. 4a. Among the three types, the inner-inner sample has the greatest shear strength value, which is $18.35 \mathrm{MPa}$. The other two kinds of samples have similar shear strength values, approximately $14 \mathrm{MPa}$, which are about $20 \%$ lower than that of the inner-inner sample. The shear strength results of the three types are all slightly higher than results of other researchers (11.33-12.84 MPa) [28]. And the reason for the difference may be microwave was employed as the heating method in this study. Figure $4 \mathrm{~b}$ shows the load-displacement curves of the three types of samples. In particular, the curves of the three types of samples can be divided into two regions. When the load reaches around $2200 \mathrm{~N}$, there are points of inflection on the load-displacement curves, and separate the curves into two regions. We will discuss this in more detail later in this paper.

\section{Morphology analysis}

Bamboo materials are mainly composed by bamboo fiber cells and parenchyma cells. On the outer side fiber content is much higher than that of the inner side, and this is in agreement with the morphology of fracture bamboo surface, as shown in Fig. 5.
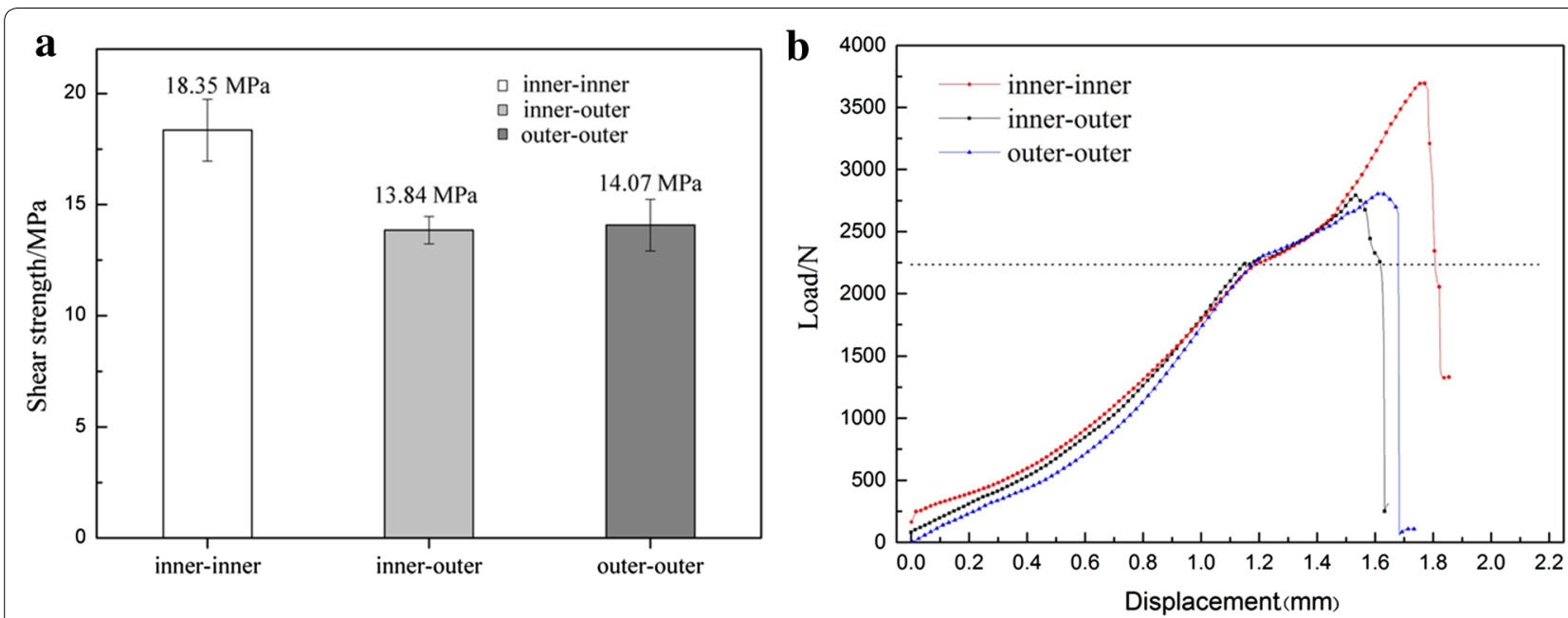

Fig. 4 a Shear strength results of the three types of glued bamboo strips; $\mathbf{b}$ load-displacement curve of compression shear test 

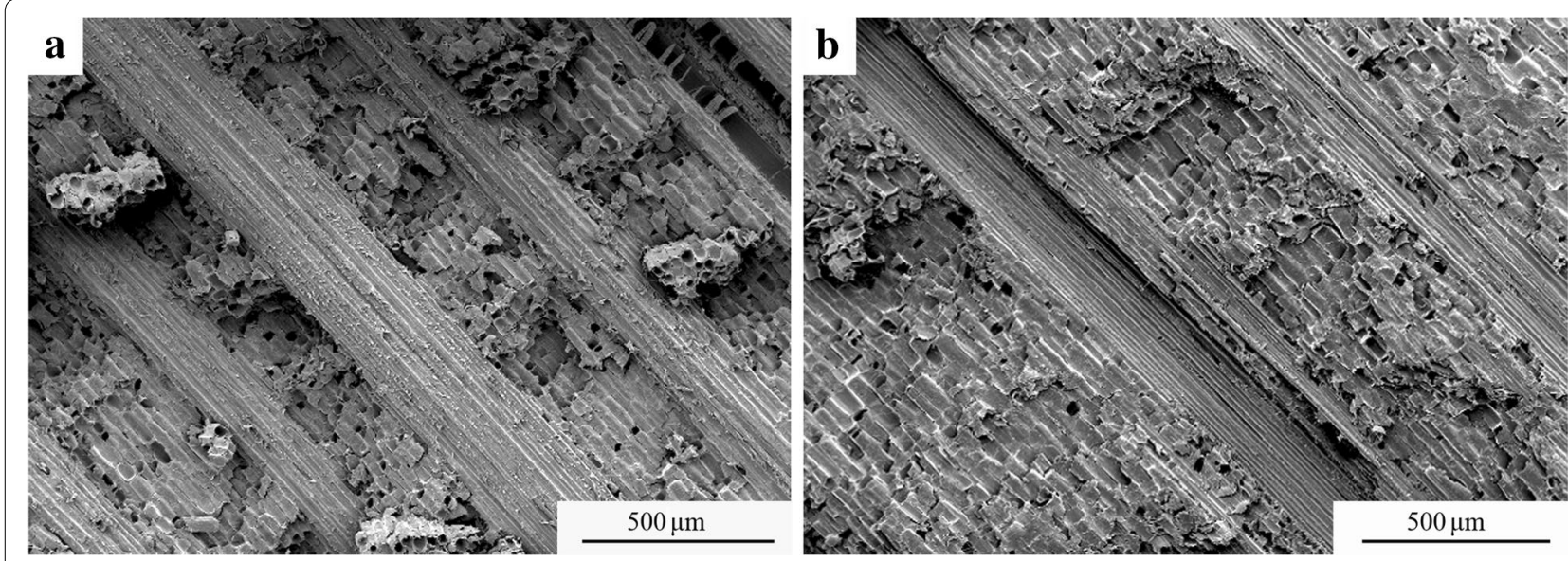

Fig. 5 Morphology of fracture bamboo: $\mathbf{a}$ the outer side, $\mathbf{b}$ the inner side

Figure 6 shows the fracture morphology of bamboo fiber cells and parenchyma cells. Figure $6 \mathrm{a}, \mathrm{b}$ indicates that the fiber cell itself is little broken in compress shear test. Under the action of shear force, there are some fibrils that warp and drop on bamboo fiber surface. And dominant destruction occurs at the interface between bamboo fibers. There are two types of cells in parenchyma in bamboo materials: long cells and short cells [14]. The long cells arrange vertically, and the short cells are scattered in the longer cells. In comparison with the long cells, the short cells have thinner cell walls and are not woody. Figure $6 \mathrm{c}-\mathrm{f}$ shows the fracture morphology of long cells and short cells. It is clear from the SEM images that the shear force will break the parenchyma cells, whether they are long cells or short cells. Fracture occurs on the wall of parenchyma cell and finally chops up the parenchyma cell.

\section{Mechanism analysis}

The bamboo has a consistent structure from top to bottom. So along the glued line, the percentage of fibers (or parenchymata) can be calculated by the ratio of fibers (or parenchymata) length to the total length of glued line, as shown in the following graphic (Fig. 7).

According to this method, ten inner-outer samples were observed and calculated. For the outer side, the percentage of fiber along the glued line is $50.28 \%$. And for the inner side, the percentage of fiber along the glued line is $18.49 \%$, which means $71.51 \%$ are parenchymata.

Figure 8 is a schematic drawing that illustrates the different functions from different elements in bamboo. The bamboo fiber cells are connected by intercellular layer $[18,29]$. The intercellular is naturally free of cellulose, whose dominant component is pectin and lignin. Cellulose is the skeleton element in biological cell wall, and cellulose is the key factor in bamboo mechanical performance.

The chemical components of intercellular layer result in its low mechanical performance, thus the interface between bamboo fiber cells is very weak. When the bamboo is broken by shear force, the weak interface will be the priority for cracks growth direction. So the fiber bundles have less contribution to shear strength of bamboo, as shown in Fig. 8a. Comparing with bamboo fiber cell, parenchyma cell is hollow and its cell wall is very thin. The size of a parenchyma cell is about $50 \mu \mathrm{m}$ to $100 \mu \mathrm{m}$, and the cell wall is only about $3 \mu \mathrm{m}$ to $5 \mu \mathrm{m}$. Thus the crack will easily break the parenchyma cell wall. Although the parenchyma cell wall is thin, its strength is much higher than that of bamboo fibers interface. Thus we consider that the parenchyma cell have greater contribution to shear strength of bamboo, as shown in Fig. 8b. In addition, the parenchyma cells are hollow structure. This means PF adhesive can infiltrate into parenchyma cells more deeply, and this is another important reason to the difference of shear strength. Since in the inner side, $71.51 \%$ cells are parenchymata, the inner-inner sample has the greatest shear strength value.

In this research, sample is broken at the bamboo part where is nearest to the glued interface. Figure 9a shows morphology of the glued interface. It is indicated from the SEM image that there is a deformable layer near the glued interface. This deformable layer includes about two to three layers of parenchyma cells, which have deformed under the action of pressure. We consider that there will be a decline of mechanical performance of the deformed parenchyma cells. Thus this deformable layer is the broken area in the shearing process. Figure $9 \mathrm{~b}$ is a schematic drawing that illustrates the shearing process. If the shearing displacement is small, 

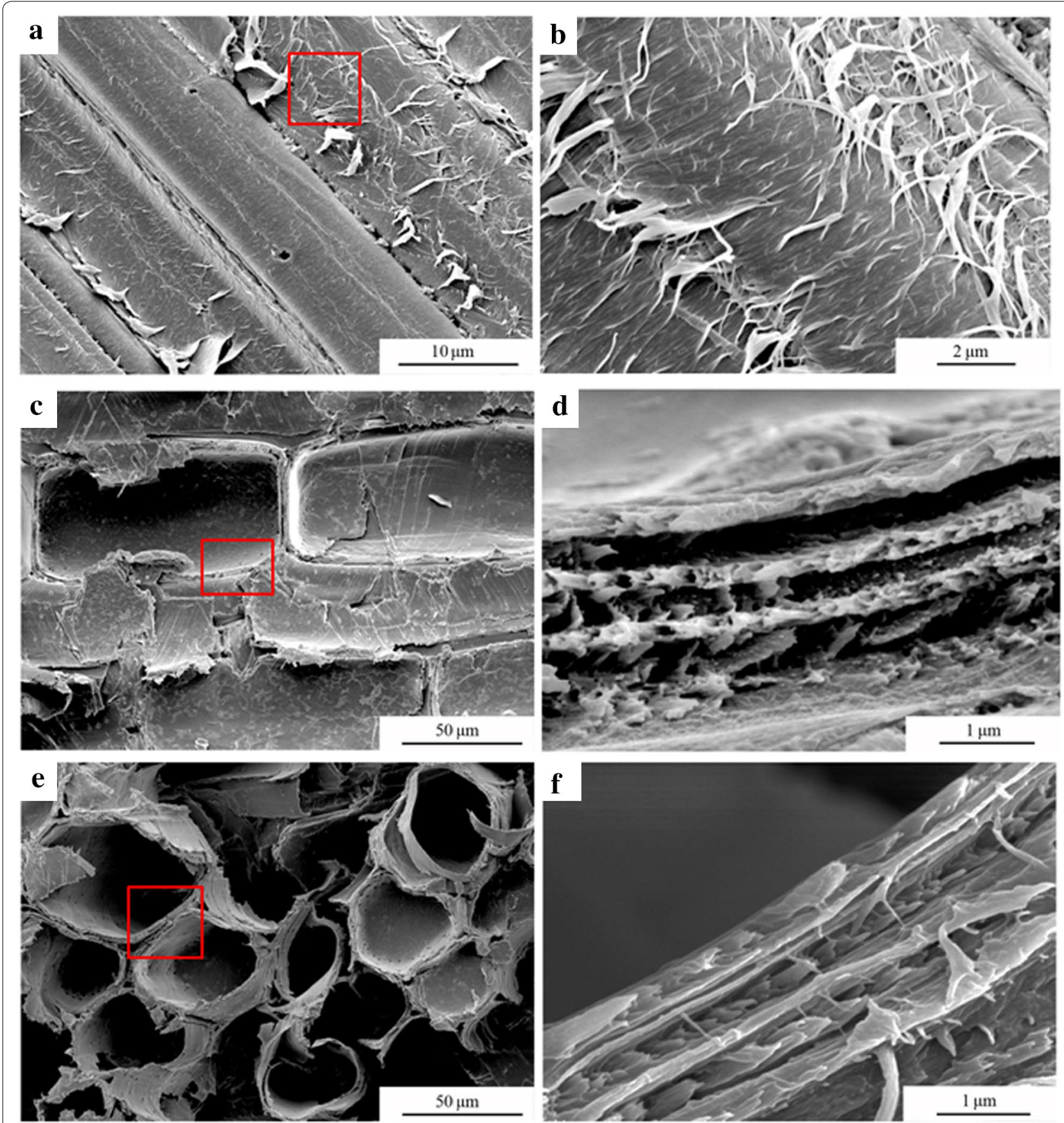

Fig. 6 Fracture morphology of bamboo fiber cells and parenchyma cells: a fiber cells, $\mathbf{c}$ long parenchyma cells, e short parenchyma cells, $\mathbf{b}$, $\mathbf{d}$ and $\mathbf{f}$ are amplifications of the marked areas corresponding to $\mathbf{a}, \mathbf{c}$ and $\mathbf{e}$

the pressed parenchyma cells will be still in the state of relaxation. Thus in the early period of shearing process, the parenchyma cells are not yet fully effective, for it is in relax status. In the later period of shearing process, the interface of bamboo fibers have been destroyed, and the parenchyma cells are tensioning with the increase of shearing displacement. At this period, parenchyma cells are the main contributor to shear strength. We consider that this is the main primary reason for the inflection on the load-displacement curves, which is shown in Fig. 4b. 


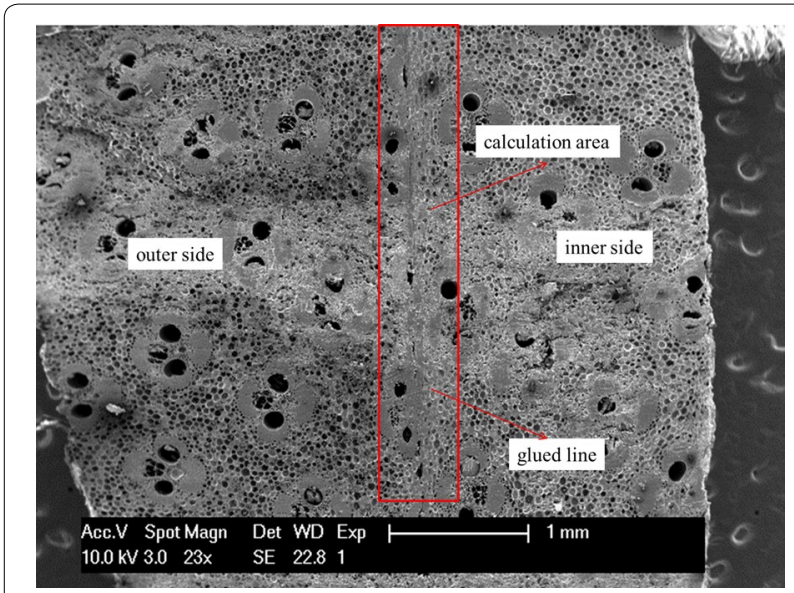

Fig. 7 Morphology of fibers and parenchymata along the glue line

\section{Conclusion}

Among the three types, the inner to inner sample has the greatest shear strength value, which is $18.35 \mathrm{MPa}$ and about $20 \%$ higher than that of the other two kinds of samples. The parenchyma cells have greater contribution to shear strength of bamboo, and the inner side of bamboo has higher parenchyma cell density, thus the inner side of bamboo has higher shear strength. In the early period of shearing process, the deformed parenchyma cells are in a relaxed status, and the parenchyma cells become tensioning with the increase of shearing displacement. Thus until the later period of shearing process, the parenchyma cells begin to contribute to shear strength.

\section{Abbreviations}

SEM: Scanning electron microscope; PF: Phenolic resin.

\section{Acknowledgements}

The authors are grateful for the support of the "The National Key Research and Development Program of China, No. 2017YFB0310400".

\section{Authors' contributions}

$Y Z$ analyzed the data and the mechanism, and was a major contributor in writing the manuscript. BY, YT and ZP conducted bulk of the experimental work in the manuscript. All authors read and approved the final manuscript.

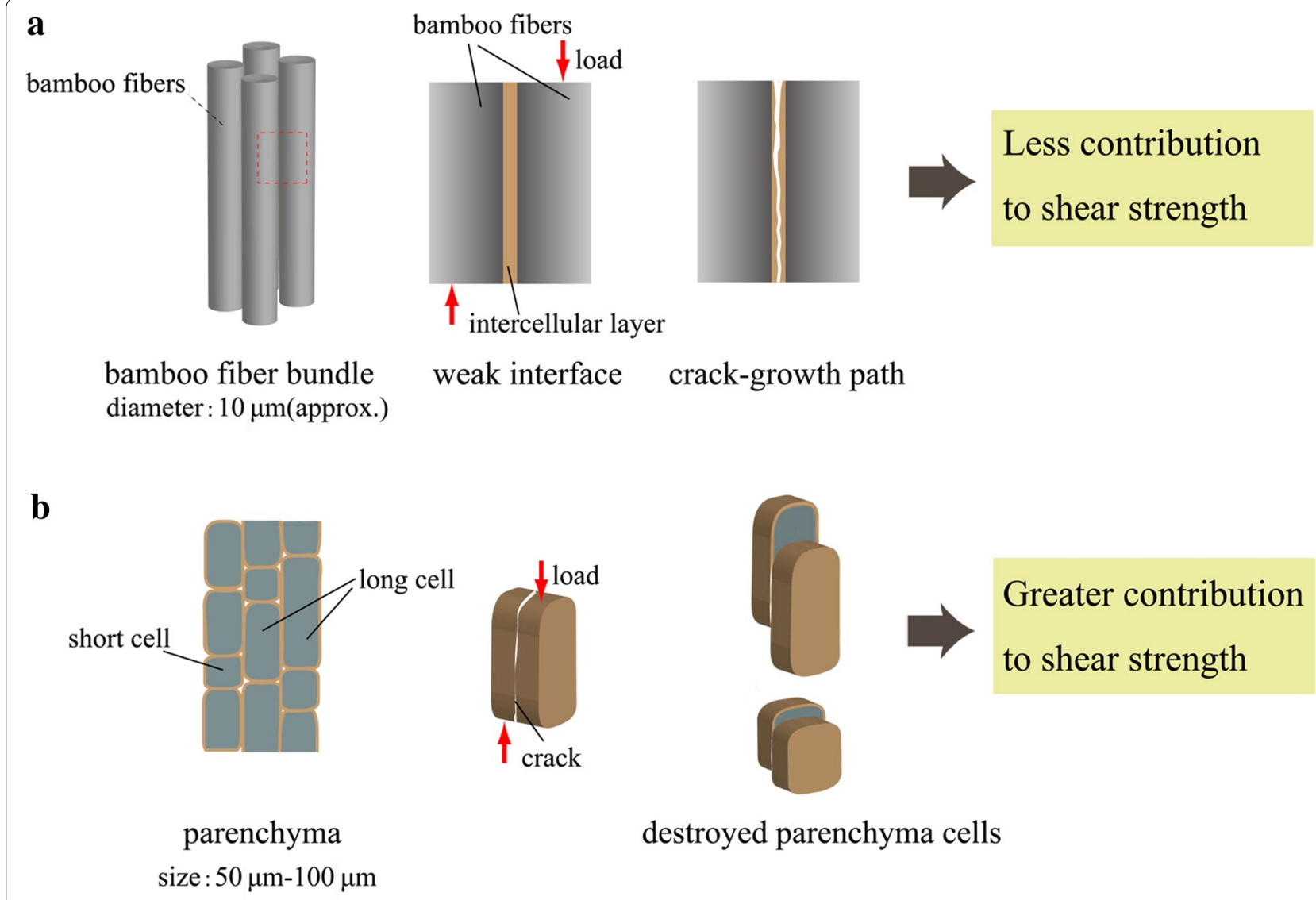

Fig. 8 Schematic drawing of function of different kinds of cells on bamboo shear strength: a fiber cells, $\mathbf{b}$ parenchyma cells 


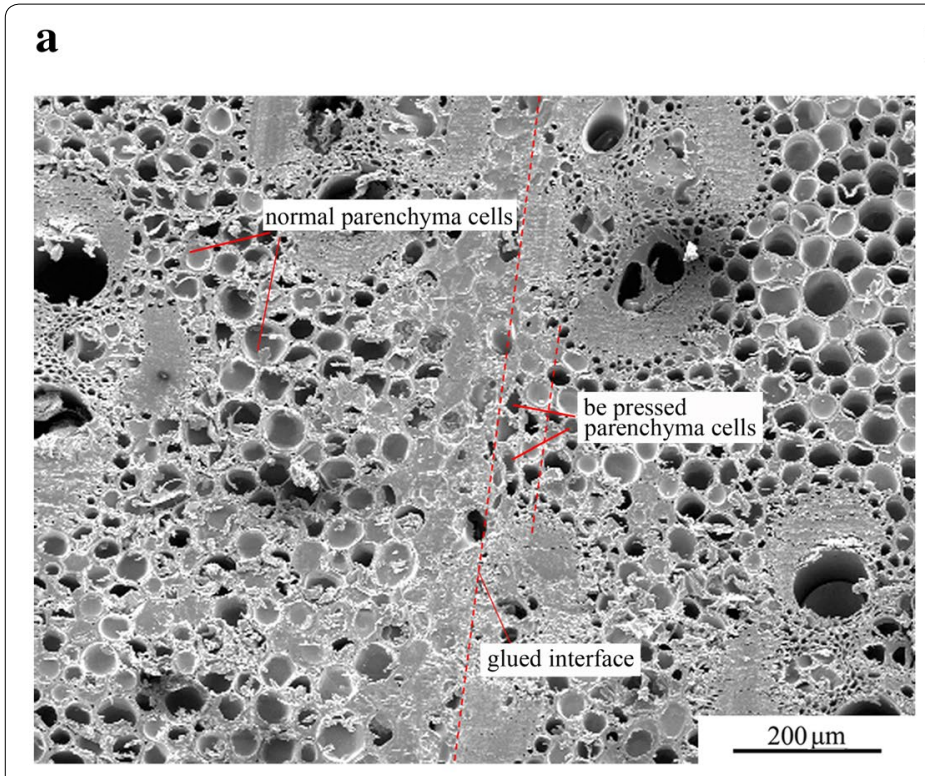

b

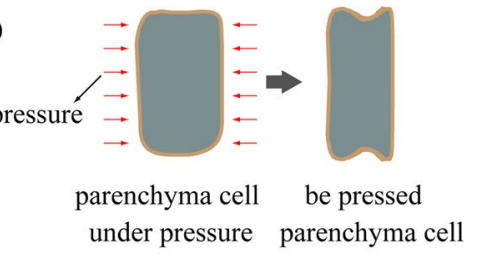

shear force

bamboo fibers parenchyma cell

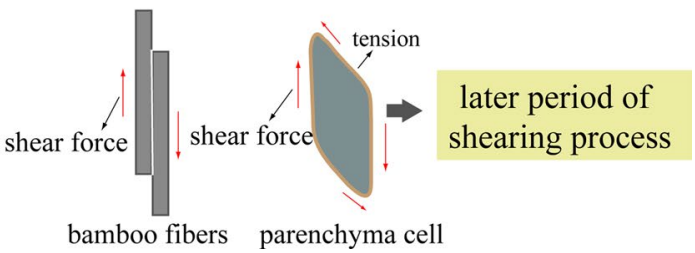

Fig. 9 a Morphology of interface of glued bamboo, $\mathbf{b}$ schematic drawing of shearing process

\section{Funding}

This work was supported by the "The National Key Research and Development Program of China, No. 2017YFB0310400".

\section{Availability of data and materials}

Not applicable.

\section{Competing interests}

The authors declare that they have no competing interests.

\section{Author details}

${ }^{1}$ Beijing Research Institute of Synthetic Crystals Co., Ltd, Beijing 10018, China.

${ }^{2}$ Beijing Cogent Mechanical and Electrical Equipment Inspection Institute,

Beijing 100007, China.

Received: 11 March 2020 Accepted: 25 August 2020

Published online: 03 September 2020

\section{References}

1. Amada S, Ichikawa Y, Munekata T, Giovanna R, Fabio Z (1997) Fiber texture and mechanical graded structure of bamboo. Compos Part B-Eng 28:13-20

2. Nugroho N, Ando N (2000) Development of structural composite products made from bamboo I: fundamental properties of bamboo zephyr board. J Wood Sci 46:68-74

3. Nugroho N, Ando N (2001) Development of structural composite products made from bamboo II: fundamental properties of laminated bamboo lumber. J Wood Sci 47:237-242

4. Tan T, Rahbar N, Allameh SM (2011) Mechanical properties of functionally graded hierarchical bamboo structures. Acta Biomater 7:3796-3803

5. Li H, Zhang Q, Huang D, Deeks AJ (2013) Compressive performance of laminated bamboo. Compos Part B-Eng 54:319-328

6. Chen H, Cheng H, Wang G, Yu Z, Shi SQ (2016) Erratum to: tensile properties of bamboo in different sizes. J Wood Sci 62:213

7. Shangguan W, Zhong Y, Xing X, Zhao R, Ren H (2015) Strength models of bamboo scrimber for compressive properties. J Wood Sci 61:120-127
8. Li Z, Liu CP, YU T (2002) Laminate of reformed bamboo and extruded fiber-reinforced cementitious plate. J Mater Civil Eng 14:359-365

9. Crow E, Murphy RJ (2000) Microfibril orientation in differentiating and maturing fibre and parenchyma cell walls in culms of bamboo. Bot J Linn Soc 134:339-359

10. Cha MY, Lee KH, Kim YS (2014) Micromorphological and chemical aspects of archaeological bamboos under long-term waterlogged condition. Int Biodeterior Biodegrad 86:115-121

11. Yamashita O, Imanishi H, Kanayama K (2007) Transfer molding of bamboo. J Mater Process Technol 192:259-264

12. Jain S, Kumar R, Jindal UC (1992) Mechanical behaviour of bamboo and bamboo composite. J Mater Sci 27:4598-4604

13. Li SH, Fu SY, Zhou BL, Zeng QY, Bao XR (1994) Reformed bamboo and reformed bamboo/aluminium composite. J Mater Sci 29:5990-5996

14. Abe K, Yano H (2010) Comparison of the characteristics of cellulose microfibril aggregates isolated from fiber and parenchyma cells of Moso bamboo (Phyllostachys pubescens). Cellulose 17:271-277

15. Zou L, Jin H, Lu WY, Li X (2009) Nanoscale structural and mechanical characterization of the cell wall of bamboo fibers. Mater Sci Eng C 29:1375-1379

16. Abdul Khalil HPS, Bhat IUH, Jawaid M, Zaidon A, Hermawan D, Hadi YS (2012) Bamboo fibre reinforced biocomposites: a review. Mater Des 42:353-368

17. Trujillo E, Moesen M, Osorio L, Van Vuure AW, Ivens J, Verpoest I (2014) Bamboo fibres for reinforcement in composite materials: strength Weibull analysis. Compos Part A: Appl Sci Manuf 61:115-125

18. Wang F, Shao Z, Wu Y (2013) Mode II interlaminar fracture properties of Moso bamboo. Compos Part B-Eng 44:242-247

19. Amada S, Untao S (2001) Fracture properties of bamboo. Compos Part B-Eng 2001:451-459

20. Bhavna S, Kent AH, Khosrow G (2013) Methods of determining transverse mechanical properties of full-culm bamboo. Constr Build Mater 38:627-637

21. Fuentes $C A$, Tran LQN, Van Hellemont M, Janssens V, Dupont-Gillain C, Van Vuure AW, Verpoest I (2013) Effect of physical adhesion on mechanical behaviour of bamboo fibre reinforced thermoplastic composites. Colloid Surf A 418:7-15 
22. Li T, Cheng D, Walinder MEP, Zhou D (2015) Wettability of oil heat-treated bamboo and bonding strength of laminated bamboo board. Ind Crops Prod 69:15-20

23. Fuentes CA, Brughmans G, Tran LQN, Dupont-Gillain C, Verpoest I, Van Vuure AW (2015) Mechanical behaviour and practical adhesion at a bamboo composite interface: physical adhesion and mechanical interlocking. Compos Sci Technol 109:40-47

24. Widyorini R, Umemura K, Isnan R, Putra DR, Awaludin A, Prayitno TA (2016) Manufacture and properties of citric acid-bonded particleboard made from bamboo materials. Eur J Wood Wood Prod 74:57-65

25. Benedetto A, Calvi A (2013) A pilot study on microwave heating for production and recycling of road pavement materials. Constr Build Mater 44:351-359

26. Leung CKY, Pheeraphan T (1995) Microwave curing of Portland cement concrete: experimental results and feasibility for practical applications. Constr Build Mater 9:67-73
27. Zheng Y, Jiang Z, Sun Z, Ren H (2014) Effect of microwave-assisted curing on bamboo glue strength: bonded by thermosetting phenolic resin. Constr Build Mater 68:320-325

28. Deng J, Chen F, Wang G, Zhang W (2016) Variation of parallel-to-grain compression and shearing properties in moso bamboo culm (Phyllostachys pubescens). BioResources 11:1784-1795

29. Parameswaran N, Liese W (1976) On the fine structure of bamboo fibres. Wood Sci Technol 10:231-246

\section{Publisher's Note}

Springer Nature remains neutral with regard to jurisdictional claims in published maps and institutional affiliations.

\section{Submit your manuscript to a SpringerOpen ${ }^{\circ}$ journal and benefit from:}

- Convenient online submission

- Rigorous peer review

- Open access: articles freely available online

- High visibility within the field

- Retaining the copyright to your article

Submit your next manuscript at $\boldsymbol{\nabla}$ springeropen.com 